Théologiques

Théologiques

\title{
Perspective Criticism and the Study of Narrative Biblical
}

Literature

\section{The Story of the Hemorrhaging Woman (Mark 5,24-34) as a Test Case}

\section{Calogero A. Miceli}

Volume 24, numéro 1, 2016

URI : https://id.erudit.org/iderudit/1044744ar

DOI : https://doi.org/10.7202/1044744ar

Aller au sommaire du numéro

\section{Éditeur(s)}

Faculté de théologie et de sciences des religions, Université de Montréal

\section{ISSN}

1188-7109 (imprimé)

1492-1413 (numérique)

Découvrir la revue

\section{Citer cet article}

Miceli, C. A. (2016). Perspective Criticism and the Study of Narrative Biblical Literature: The Story of the Hemorrhaging Woman (Mark 5,24-34) as a Test Case. Théologiques, 24(1), 167-183. https://doi.org/10.7202/1044744ar

\section{Résumé de l'article}

Dans ses travaux récents, Watching a Biblical Narrative : Point of View in Biblical Exegesis (2007) et Perspective Criticism : Point of View and Evaluative Guidance in Biblical Narrative (2012), Gary Yamasaki présente une nouvelle méthodologie, intitulée Perspective Criticism, pour examiner les textes bibliques. Cet article démontre que la méthode proposée est un outil viable pour l'étude des textes bibliques. Il prend le récit de la Femme hémorragique (Marc 5,24-34) comme exemplaire. Dans ce texte, le lecteur implicite reçoit des informations sur l'histoire et la motivation de la femme hémorragique. Plutôt que de se concentrer uniquement sur le protagoniste Jésus, le narrateur déplace l'attention du lecteur sur la femme et explique ses échecs, au fil des ans, dans la recherche d'un remède à sa maladie. En employant la méthodologie perspective critique, l'étude soutient que l'auteur implicite a délibérément inséré cette information privilégiée, qui est anachronique au temps narratif de la péricope, afin de susciter l'empathie du lecteur avec la femme. Le récit offre la possibilité de voir les événements antérieurs du point de vue de la femme afin de comprendre son conflit tragique et de se rapprocher émotionnellement à ses pensées intérieures. 


\title{
Perspective Criticism and the Study of Narrative Biblical Literature
}

\section{The Story of the Hemorrhaging Woman (Mark 5,24-34) as a Test Case}

\author{
Calogero A. Miceli" \\ Department of Religions and Cultures \\ Concordia University (Montreal, Canada)
}

At a time when the field of biblical studies is laden with an abundance of methods for interpretation including, but certainly not limited to, historical criticism, redaction criticism, textual criticism, narrative criticism, reader-response criticism, structural criticism, performance criticism, social-scientific criticism (which includes anthropological approaches, psychological approaches, and sociological approaches), rhetorical criticism, socio-rhetorical criticism, literary criticism, post-colonial criticism, postmodernist criticism, form criticism, and genre criticism, the question must certainly be asked whether there is need and room for yet another criticism. Any new methodological approach should not be harshly judged or discounted merely because the field is already burdened with such a plethora of criticisms. Rather, if one is to introduce a new method for analyzing biblical stories then said method should be judged according to its usefulness for biblical criticism, i.e. the study and investigation of biblical writings. Ergo, if a new methodological approach for better understanding the texts is presented then it would be appropriate to explore the potentials and limitations of said criticism in order to properly assess its expediency in this enterprise.

* Calogero A. Miceli is a Ph.D. Candidate and course instructor in the Department of Religions and Cultures at Concordia University. His current research focuses on early Christian literature and history, New Testament, apocryphal Christian texts, contemporary methodological approaches to the study of religion, Bible and popular culture, and religion and violence. Miceli has recently co-edited (2016), with A. Gagné, and S. Loumakis, The Global Impact of Religious Violence, Wipf and Stock. 
The following paper is aimed at partially accomplishing this task. I say partially because the usefulness and longevity of a methodological approach cannot and will not be appropriately measured or evaluated by a single study. Rather, the wealth of an approach to scriptural texts will be realized over the course of many years and studies; owing to its ability for begetting new ideas and discussions from the ancient religious texts that we continue to study today. Therefore, the following paper looks to make use of the newly proposed method designated as «Perspective Criticism» introduced by Gary Yamasaki. In order to establish whether the application of this method can yield fruitful results the paper examines a particular pericope, in this case the story of Jesus healing the hemorrhaging woman in Mk 5,2434. Granted, the story of the hemorrhaging woman was not randomly selected, but chosen intentionally in order to demonstrate the potential effectiveness that this approach can have on our understanding of a biblical story. Even if the application to a text is pre-determined, the study nonetheless serves as a test case for evaluating the method since others can observe how perspective criticism performs in illuminating this account and can judge for themselves, in criticism or in further employment of the approach, whether this is a fashion in the field that is short lived or that endures.

The following essay uses perspective criticism in order to explore the story of Jesus healing the hemorrhaging woman (Mk 5,24-34), specifically the contextual information about the history and motivation of the woman. Why is the audience informed about the woman's backstory and what is the purpose of this inclusion? In what follows it is argued that this privileged information - which is achronological to the narrative time of the pericope - has been purposefully inserted in order to elicit empathy from the reader with the woman. The focus on Jesus is set aside in order to present the audience with the point-of-view of the woman, her tragic struggle and her inner thoughts so as to create an emotional connection between the audience and the character of the hemorrhaging woman. The implication for such a perspective is critical in helping the overall story establish Jesus' powers for healing, but also, and more importantly, for bringing the reader into a frame of mind whereby the trust and faith in Jesus is seen to yield first-hand results in a more personal way than if the inner thoughts of the woman were not present otherwise.

\section{Defining Perspective Criticism}

In his recent works, Watching a Biblical Narrative: Point of View in Biblical Exegesis (2007) and Perspective Criticism: Point of View and Evaluative 
Guidance in Biblical Narrative (2012), Gary Yamasaki (Professor of Biblical Studies at Columbia Bible College in Abbotsford, British Colombia) has introduced a new method for analyzing narrative biblical literature, which he has termed «Perspective Criticism». With this new approach Yamasaki, «seeks to develop a methodology for analyzing point-of-view that provides biblical scholars with a tool that will enable them not only to recognize point-of-view moves in a passage of biblical narrative, but also to discern the significance of these moves for the interpretation of the passage » (Yamasaki $2007,3)$. In order to grasp the literary concept of point-of-view ${ }^{1}$, one must first be acquainted with the role of the narrator who the author likens to the director of a cinematic film (Yamasaki 2012, 2-6). The narrator of a literary text is responsible for every word and sentence in the entirety of a story and the reader learns everything about the story from the words of the narrator (Yamasaki 2012, 4-5). The narrator guides the evaluation of the story for the audience and this evaluative guidance is at the heart of the Perspective Criticism methodology.

How, then, does the role of the narrator differ from the role of the implied author? The distinction between these entities is ambiguous. As Elizabeth Struthers Malbon has noted, "Most narrative critics have observed little or no difference between the implied author and narrator or between the narratee and implied reader of Matthew, Mark, Luke, and John... Thus, some narrative critics use the terms narrator and narratee, and others employ implied author and implied reader" (Malbon 1992, 28). For methodological purposes, I clarify that while Yamasaki uses the broader term "narrator» to describe the entity that guides the reader in the story and that makes the narrative decisions, I refer to this figure as the implied author throughout the course of this essay. Similarly, throughout the essay, when I refer to the reader or audience of the text, I am referring specifically to the implied reader. The implied reader refers to the image of the readership imagined by the implied author ${ }^{2}$.

1. Perspective Criticism utilizes point-of-view which refers to the outlook from which a narrator conveys a story. Literary critics typically refer to four planes of point-ofview: Phraseological (phrases and words used in a narrative); Spatio-Temporal (where and when of events); Psychological (thoughts and behaviours of characters); and Ideological (the worldviews of the narrator). For more information on point-ofview see: Yamasaki (2012, 167-173); also Resseguie (2005, 172).

2. Though the field of Biblical Studies has generally moved beyond the implied/real/narrative author and reader, I nevertheless think the distinctions are worth maintaining. 


\section{Literary Context}

So [Jesus] went with him. And a large crowd followed him and pressed upon him. A woman who had been with hemorrhaging for twelve years and had suffered plenty under plenty of physicians had spent everything she had and did not benefit, but rather came out worse. She had heard about Jesus, came up behind him in the crowd, and touched his clothing, for she said, «If I but touch his clothes, I will be healed ». Immediately her hemorrhaging stopped [lit. became dry] and she realized her body was cured from the affliction. Immediately Jesus realized his power came out of him. He turned around in the crowd and said, "Who touched my clothes?" And his disciples said to him, "You see the crowd pressing in on you and you say, "Who touched me?" ". He looked around to see who had done this. But the woman was terrified and trembling, having known what had happened to her. She came, fell down before him, and told him the entire truth. Then he said to her, "Daughter, your faith has healed you; go in peace, and be healed of your affliction» (Mk 5,24-34) ${ }^{3}$.

The story about Jesus healing the hemorrhaging woman in Mark's gospel is set in the middle of a larger narrative in which Jesus brings back to life the daughter of Jairus ( $\mathrm{Mk} 5,21-43)$. While on his ministry, Jesus is asked to heal Jairus' daughter $(5,21-24 a)$ and on the way happens to find himself in a new situation which, even without his knowledge, turns out to be another healing story $(5,24 b-34)$. After the hemorrhaging woman is healed of her sickness, Jesus resumes his initial mission, to heal Jairus' daughter, which he finally arrives to and completes in 5,35-43.

This insertion, of a story within a story, is a typical Markan literary practice commonly referred to as a "sandwich technique» (Edwards 1989). In the intercalation, Mark interrupts one story with another story until coming back to the first - a technique also used throughout the gospel in Mark 3,20-35; 5,21-43 ; 6,7-30; 11,12-21; 14,1-11; 14,53-72. Adela Yarbro Collins surmises that in the case of the Jairus and hemorrhaging woman accounts, since each story can stand individually apart from the other, then the insertion of one into the other may likely reflect that the stories were originally separate sources (Collins 2007, 276). Avoiding the very important question of the original form of the stories prior to their inclusion into Mark's gospel, as it stands and is presented in Mark what we have are two connected events. The purpose for this con-

3. All translations are mine unless otherwise noted. 
nection, argue Marguerat and Bourquin in their book How to Read Bible Stories, "triggers off an echo between the scene inserted and the scene into which it is inserted, and this echo produces enhanced meaning: the two scenes interpret each other» (Marguerat and Bourquin 1999, 39). As James Edwards has argued concerning the technique in Mark: «the sandwiches emphasize the major motifs of the Gospel, especially the meaning of faith, discipleship, bearing witness, and the dangers of apostasy » (Edwards 1989, 196). In the case of the hemorrhaging woman and the story of Jairus, Edwards sees faith as the center of the intercalation and as the key to understanding the meaning behind the sandwiching of the hemorrhaging woman account into the story of Jairus (Edwards 1989, 205), an idea that is further taken up later on in the essay ${ }^{4}$.

\section{The Hemorrhaging Woman's Past}

The story of Mark 5,24-34 is told in a way that allows the audience to feel a sense of attachment; the reader is led to feel a connection with the hemorrhaging woman. This connection is not present when one reads the similar, yet much briefer account of healing through clothing, also found in Mark's gospel. In a subsequent part of his ministry in Mark, Jesus is said to have performed a miracle, which also involves the mention of his clothes:

When they came out of the boat, immediately people recognized him and ran around that whole region and they began to carry the afflicted on mats wherever they heard he was. So wherever he went, into villages or into cities or into farms, they laid the sick in the agorae, and they begged him that they might touch even the fringe of his clothing; and all who touched it were healed. (Mark 6,53-56)

Aside from the fact that the story of Jesus healing the sick in 6,53-56 is briefer than the account of the hemorrhaging woman, one more important variance is that in the former we are given firsthand information about the woman from her own thoughts. In the second account, the story is succinct and serves mainly to showcase that Jesus is performing miracles

4. While all of this information sheds light on the literary context of the account of the hemorrhaging woman, the connection of this story to the healing of Jairus' daughter is not the focus of, and will not be explored in, this essay. Our interest, rather, is the construction of the story of the woman with blood-flow and the emphasis on the point-of-view of the secondary character. 
and healing the sick people that he encounters during his ministry ${ }^{5}$. The thoughts that we find in the story of the hemorrhaging woman are important because, as I argue, they allow the implied audience to feel connected to the story and empathize with the sick woman character.

The account of the hemorrhaging woman is not presented chronologically. Though there is a shift in time between the request of Jairus and Jesus' arrival to his home later on ${ }^{6}$, this is not the time I am focusing on here. Rather, I refer to the part in the story when we read that Jesus was walking with a large crowd pressing upon him in verse 24 . There is a shift in narrative time that occurs in verse 25 whereby the story is no longer continuing linearly (Powell 1990, 36-39). Instead, the narrative time shifts from following Jesus and the crowd on the way to Jairus' home to a flashback sequence where information about the background of a new character is introduced to the reader. This sequence, of a flashback evoking, at a later time, an event that has transpired prior from the current point-ofview of the story, is commonly referred to as an analepsis in narrative terms (Marguerat and Bourquin 1999, 89-91). This pause marks the implied author's manipulation of the story time in which the narrative takes a step back in order to explain the history of the woman who is being introduced. We, as audience, are transported from Jesus' ministry to a rapid summarization of past events in which the woman has visited a number of physicians, but has not been cured of her ailment. The shift functions much like a flashback episode.

The implied author can construct the story in any way. When in the process of writing, the author has the ability, like a film director, to pick and choose what will be shot and how near or far that shot will be (in other words how much information or lack of information will be provided to the audience). It is not so much that we, as the audience, are following Jesus as he makes his way to Jairus' house; rather, it is the implied author who makes the choice to put on display and emphasize that part of the story. One who is reading the text could simply have been told that

5. In some ways, this account may evoke memories of the previous healing story where the haemorrhaging woman was desperate for healing.

6. When reading the entire episode it is clear that time has elapsed between Jairus' request $(5,22)$ and Jesus' arrival to Jairus' home $(5,35)$. This lapse in time and the event with the hemorrhaging woman may actually account for the death of Jairus' daughter when Jesus arrives. The episode of the hemorrhaging woman then is a plot inserted in order to show the progression of this time between the request on the part of Jairus and Jesus' arrival. 
Jesus followed Jairus until people come from the house to inform Jairus that his daughter is already dead. Had that been the case, the audience would not have found this construction odd or questioned it in any way ${ }^{7}$. The audience would not ever have known about the hemorrhaging woman or her disease. But, the implied author has chosen to emphasize the journey that Jesus takes from meeting Jairus to arriving at Jairus' home, a decision that is important for understanding the emphasis that the implied author is creating. Very much like a tour guide or film director (Yamasaki 2012, 7), the implied author gives the audience a certain vantage point in the story of the gospel. In this case, the vantage point is in the history of the woman's struggle with her ailment.

Not only is there a decision to emphasize the journey of Jesus from the other side of the lake to Jairus' home (by having the inserted sandwich account of verses 24-32), but there is also a decision made to change the focus and perspective of the story from Jesus to an entirely new character. This shift occurs in the spatial plane of point-of-view from the protagonist Jesus, to the hemorrhaging woman. The implied author, in presenting the woman to the audience, does not hide her identity, but instead immediately offers an explanation of who she is: "A woman who had been with hemorrhaging for twelve years and had suffered plenty under plenty of physicians had spent everything she had and did not benefit, but rather came out worse» $(\mathrm{Mk} \mathrm{5,25-26)}$. At this point, the audience does not have to ask about the history of this woman because that information is immediately provided for them upon her introduction into the story. Even before she touches Jesus and before the audience can question any of her motives for placing her hand on Jesus' clothing, they are already made aware of the woman's condition; she suffers from hemorrhaging and has been suffering for twelve years ${ }^{8}$. Collins makes an important comment on the text which informs the reader that the woman had spent all that she had, writing that this detail is indicative of the fact that at one point she could financially afford to consult more than one physician, but the search for healing, «had resulted in the depletion of her assets, so that the

7. From a redactional perspective, this may have very well been the case in the original stories as they were constructed prior to Mark's modifications.

8. Collins remarks that the number does not seem to have any symbolic meaning and is only meant to emphasize the lengthiness and gravity of her suffering (Collins 2007, 280); Guelich, on the other hand, surmises that the twelve years of suffering is less than coincidental since it connects with the story of the daughter of Jairus who was twelve years old (Guelich 1989, 296-297). 
audience may infer that she was desperate at this point» (Collins 2007, 281). We see firsthand how the analepsis of the woman and her past struggles illustrated for the reader - information about the woman that would not otherwise be known - impacts the perspective of the character for the audience. Informing the audience that she has spent everything that she had helps to establish empathy for her. By seeing her point-ofview one is more easily drawn to accepting and relating to the character and her experiences.

\section{Point-of-View of the Hemorrhaging Woman}

Immediately following the information about her past are the actions of the woman. The writer describes the actions that are taking place: "She had heard about Jesus, came up behind him in the crowd, and touched his clothing, for she said, "If I but touch his clothes, I will be healed" » (Mk $5,27-28)$. Here, the story has transitioned and returned back from explaining the woman's past struggles with her ailment to Jesus's encounter with the woman; once more we see a shift in the spatio-temporal point-of-view. Through the choices of the implied author, the audience follows Jesus on his ministry as he walks to Jairus' house with the crowd pressing on him. Then, the implied author transports the audience from that time, place and character to a time and place where the woman is suffering with hemorrhaging for twelve years and remains uncured. Next, the implied author returns to the crowd and Jesus walking on the way to Jairus' home where the perspective is placed on the woman coming up behind Jesus to touch his clothing. The action of touching Jesus' clothes is followed with an explanation for the woman's gesture, i.e. that she believes that she will be healed as a result. The perspective is now shifted away from Jesus the protagonist, and it is fixed upon the woman. Not only do we follow her actions, but the audience is also given insight into the psychological pointof-view of the character. This psychological point-of-view, based on Boris Uspensky's (1973) A Poetics of Composition, is described by Resseguie as inner emotions, thoughts, and dispositions of a character that bring forth a new point-of-view (Resseguie 2005, 35-53). This information, also referred to as 'internal focalization' (Marguerat and Bourquin 1999, 74), reveals the reasoning behind the character's actions. The woman believes that if she touches the protagonist's clothing that she will be healed of her ailment and indeed, following her inner thoughts the text reveals that, «immediately her hemorrhaging stopped» (Mk 5,29). 
If the implied author had not informed the reader about the woman's past and about her speculation for touching Jesus' clothes, then this would lead one to assume any number of reasons about her motives; however, the flashback and the internal monologue are purposefully included by the implied author in order to aid the audience's perception and perspective by explaining to them (1) who this character is and (2) what her intentions and motivations are. As Yamasaki has observed concerning this story:

[T] he narrator does not simply proceed directly to details related to the healing. Instead, he first inserts a statement on the suffering she had endured under the treatment of many doctors, and the depleting of her resources at their hands (v. 26). With this information, the readers' information database moves from a sharp divergence from the woman's database toward more of a convergence with that of the woman, the readers now having become aware of some key information related to the woman's backstory. And this simple supplying of information on the woman's background contributes toward the readers coming to merge with her. (Yamasaki 2012, 58)

When Yamasaki explains that that the reader is merged with the character of the woman, he no doubt means that there is an integration that occurs between the way in which the reader understands the woman and her motives. The information and her backstory, along with the psychological point-of-view, all function to familiarize the audience with the woman. The audience can understand and empathize with both her situation and subsequent action of touching Jesus' clothing. The reader, in being exposed to the evaluative point-of-view of the woman, is able to connect with her. The audience feels sympathy for the woman when they learn about her struggles with her illness and then can empathize with her when they are privy to her inner thoughts as she decides to touch Jesus' clothing?

\section{Realization \& Perspective}

The focus on the woman does not change after she touches Jesus' clothes. Instead, there is a transformation that occurs. The blood dries up immediately as the woman realizes that her body is cured and then Jesus realizes that power has come out of him. The connection between these two occurrences cannot be overlooked. Both the woman's and Jesus' transformation

9. For further information about empathy and sympathy for a character see: Powell (1990, 56-58). 
are described as having occurred, «immediately» and both characters have a realization. At the heart of the story Petri Merenlahti sees a power exchange between Jesus and the woman and this power is depicted once from the woman's point-of-view and another time from Jesus' point-ofview (Merenlahti 1999, 65). The healing transformation of verse 29 is a verification of the woman's conviction when she surmised that if she touched his clothing she would be healed.

Though the audience might make the assumption that Jesus has superior knowledge of what was happening to him in the story, as he does in Mk 2,8 and 12,15 10 , here Jesus turns around and asks the crowd who has touched him. Jesus, therefore, does not know who touched his clothing. All that he is aware of is that power has come out of him. That Jesus does not know who touched him has been a problem in the story that many commentators, over the years, have tried to remedy one way or another. For example, Cranfield writes, «A good many earlier commentators (including Calvin) think that Jesus knew all the time who had touched him, and asked simply to make her confess her faith" (Cranfield 1972, 185). How does the protagonist Jesus not know who has touched him? Some writers, in trying to remedy this supposed weakness on the part of Jesus, have gone so far as to posit that the reason that Jesus does not know who touched him is because God is the one responsible for the miracle (Cranfield 1972, 185). Lane writes, "The healing of the woman occurred through God's free and gracious decision to bestow upon her the power which was active in Jesus» (Lane 1974, 193). However, the lack of any specific mention to the character of God in this episode would make this suggestion highly improbable and outright senseless. The revisionist need to justify or cover-up the lack of knowledge that Jesus displays in this scene is often theologically motivated on the part of some commentators.

What is important for us is perspective and it is clear that Jesus' perspective in this scene is different than our own, as audience. The implied author has hitherto provided the reader with information to which we would otherwise not have access. We saw this with the internal focalization in verse $27 \mathrm{a}$ when informed that the woman had heard about Jesus, in verse 28 with her interior monologue, and in verse 29 when we are apprised that her hemorrhaging has ceased. The wealth of information

10. "At once Jesus perceived in his spirit that they were discussing these questions among themselves » $(\mathrm{Mk} 2,8)$; « But knowing their hypocrisy, he said to them » (Mk $12,15)$. 
provided has given the audience a «superior position to the characters in the story, including Jesus!» (Marguerat and Bourquin 1999, 75). In fact, the audience is in a position where they are privy to information about the hemorrhaging woman as well as privy to information about Jesus (in verse 30) to which the other characters are unaware. Since the narrator in Mark is trustworthy ${ }^{11}$, the audience knows that all of the information being provided is valid and authentic. We know that the woman's hemorrhaging has ceased and that Jesus has felt power come out of him. The audience does not question that the woman's faith is sincere, that her illness is cured and that Jesus and his clothing are responsible for the cure despite the unusual fact that the protagonist of the story does not yet know whom he has cured ${ }^{12}$. Though the knowledge of the characters in the story may be limited, the audience is fully aware of everything that is transpiring and, as a result, is better equipped to make judgments about the figures in the text.

The subsequent actions on the part of the hemorrhaging woman are described to the reader from the third person point-of-view and little more insight into her character is given. The implied author explains that when Jesus looks around to see who had touched him, that the woman is in fear and trembling because she knows what happened to her and she falls before Jesus telling him the truth $(5,32-33)$. There is a shift back to Jesus as the main figure of the story and his position of authority within the story. The point-of-view shift back to Jesus coincides with a shift in power and authority. The woman's actions speak to this authority as she falls before him and tells him all that has transpired.

Without inside information about the woman's past and her inner thoughts, the impact of the story for the audience would not be the same. If one were to read that a woman came behind Jesus and touched his clothing without him knowing, the audience might surmise any number of reasons for her actions and might perhaps see this action antagonistically, in that the woman touched Jesus without his consent and for unknown motives. The information that is provided helps to guide the audience's evaluation of the hemorrhaging woman character and allows for them to empathize with her suffering and logic. In the realization of her faith and belief that Jesus would cure her, the audience is encouraged to emulate her

11. For a discussion and explanation about the trustworthiness or untrustworthiness of narrators, see: Marguerat and Bourquin (1999, 10-11).

12. For information about the important role of clothing in Mark's gospel from a narrative-critical perspective, see: Miceli (2011); Haulotte (1966, 100-102). 
attitude and perspective on the power of Jesus. The inner thoughts allow the bond to be created between secondary character and audience whereby the reader is persuaded into thinking in the same manner as the woman. Jesus' words at the end of the pericope, when he tells the woman that her faith has healed her in verse 34 , is further evidence that this trait is to be mimicked. This is how the implied author has constructed the story, with an emphasis on merging the points-of-view of the woman with that of the audience so that they may witness her genuineness and empathize with her.

What are the motivations behind the implied author's decision to give the audience the woman's perspective, beyond simply stating that this allows for a connection to be made? Why has the implied author chosen to showcase the history of the woman and her inner thoughts? The historical context of the story might provide some answer to this very important question about the implication of the implied author's choices. France states that the "mental portrait of the woman's situation before her story begins $[. .$.$] predisposes us in her favour, despite the unappealing nature of$ her complaint, especially in light of Jewish purity laws » (France 2002, 236). France is referring here specifically to the issue of menstrual impurity as it is expressed in Leviticus 15,19-33. The woman, in touching Jesus, may be violating the purity code (Donahue et Harrington 2002, 174) ${ }^{13}$. If the audience would have immediately questioned the woman's touching of Jesus because of her impurity then it would stand to reason that the inclusion of the analepsis and her inner thoughts aid in circumventing the audience's negative perception of the woman and her impurity. The audience, then, can empathize with her story rather than dismiss her outright for her actions because of her impurity. The implied author has made it a point to showcase the backstory and inner thoughts of the woman so that they might come to empathize with her, rather than disapprove of her, as soon as she is introduced into the story.

\section{Conclusion}

A partial aim of this study was to test the method of Perspective Criticism for use in biblical studies. While the methodology has already been utilized prior to this study ${ }^{14}$, it is still in its infancy and not yet widely known. This

13. For discussion on this important issue see also: Fonrobert $(1997,121-140)$; Haber (2003, 171-192).

14. See: Yamasaki $(1998 ; 2006,89-105)$. Additionally, the method has been used in various online essays and blog postings at the website dedicated to Perspective 
study, then, was intended to test case the point-of-view approach and assess whether or not it can help scholars to better understand biblical texts.

There is a need for scholars of literary criticism to embrace point-ofview as part of their analysis in biblical studies. Only time will tell whether or not the application of point-of-view will lead to continued use of the perspective criticism method or, if like structural exegesis, it will fall to the wayside (Hurtado 2014, 299-324). This author's opinion is that the method may yet prove to find an important place in the world of biblical criticism mainly because it can bypass the major problem of structuralism and post-structuralism which, as argued by Larry Hurtado, was that, « hardly (or at least rarely) was [it] demonstrated that either approach had anything terribly important to offer by way of opening texts up in new and interesting ways » (Hurtado 2014, 301). I believe that perspective criticism does have something important to offer the field of biblical criticism and it can aid in unlocking innovative understandings for biblical texts, but perhaps too for non-canonical biblical literature, an avenue for the method I hope to see develop in future studies.

One of perspective criticism's strengths is that the approach functions as a window into the inner mechanics of a biblical story. The critic's attention is less focused upon partaking in the story as it is with trying to understand the ways in which the story was assembled and the reasons for why the implied author has chosen to include particular information or highlight certain elements over others. Moving away from being receivers of the text to a place where one can question and examine the construction of a story is paramount for a greater understanding of why the story was produced and presented in a particular manner. In the case of Mk 5,24-34, it becomes clear that the implied author has made it a point to inform the reader about the backstory of the woman in order for an empathetic connection to be established between audience and secondary character. Still, the perspective of a character does not always entail empathy on the part of the reader. Rather, the insights into the thoughts of characters can be employed as a means of distancing the reader from said character and in order to create animosity or antipathy for them (Powell 1990, 56-58). This is illustrated, for example, with the story of Mk 12,13-17 in the "Question about Paying Taxes» episode. Here, the audience is given insight into the thoughts of the secondary characters, not as a way to connect with them, 
but to show that they are distrustful and antagonists to Jesus. As it says, «they sent to [Jesus] some Pharisees and Herodians so that they might trap him in his talk» (Mk 12,13). One must backtrack to Mk 11,27 in order to understand that the 'they' referred to here includes the chief priests, the scribes and the elders. Though it is already clear for the reader that these characters are out to get Jesus even before the episode of Jesus and the denarius, the example nonetheless serves to illustrate the point that the inclusion of inner thoughts or dialogue that are not necessarily essential for the plot of the story, are fundamental for the relationship the reader is being led to make by the implied author with the characters of the story.

While the argument might be made that the type of approach at the heart of Perspective Criticism is already available in handbooks on Narrative Criticism (by Powell, Resseguie, Marguerat and Bourquin, and so forth), there has not been an abundance of focus on point-of-view in the study of biblical texts. Yamasaki's method may help to fill that void and provide a specific method for understanding the evaluative guidance of the writer of the text. When critics are able to explore, in more depth, the composition of a story as opposed to being caught up in its conveyance, then fruitful interpretations are bound to emerge as a result.

\section{References}

Collins, A. Y. (2007), Mark. A Commentary, Minneapolis, Fortress Press (Hermeneia Commentary Series).

Cranfield, C. E. B. (1972), The Gospel According to Saint Mark. An Introduction and Commentary, London, Cambridge University Press (Cambridge Greek Testament Commentary).

Donahue, J. R. and D. J. Harrington (2002), The Gospel of Mark, Collegeville, Minnesota, The Liturgical Press (Sacra Pagina Series volume 2).

Edwards, J. R. (1989), "Markan Sandwiches. The Significance of Interpolations in Markan Narratives ", Novum Testamentum, 31/3, p. 193-216.

France, R. T. (2002), The Gospel of Mark. A Commentary on the Greek Text, Grand Rapids, Eerdmans (The New International Greek Testament Commentary).

Fonrobert, C. (1997), «The Woman with a Blood Flow (Mark 5,24-34) Revisited. Menstrual Laws and Jewish Culture in Christian Feminist Hermeneutics ", in C. A. Evans and J. A. SANDERs, ed., Early Christian 
PERSPECTIVE CRITICISM AND THE STUDY OF NARRATIVE BIBLICAL 181

Interpretation of the Scriptures of Israel. Investigations and Proposals, Sheffield, Sheffield Academic Press (Journal for the Study of the New Testament Supplement Series 148), p. 121-140.

Guelich, R. A. (1989), Mark 1-8,26, Waco, Word Books (Word Biblical Commentary 34A).

Haber, S. (2003), "A Woman's Touch. Feminist Encounters with the Hemorrhaging Woman in Mark 5,24-34 ", Journal for the Study of the New Testament, 26/2, p. 171-192.

Haulotte, E. (1966), Symbolique du vêtement selon la Bible, Paris, Aubier (Théologie 65).

Hurtado, L. W. (2014), «Fashions, Fallacies and Future Prospects in New Testament Studies ", Journal for the Study of the New Testament, 36/4, p. 99-324.

Lane, W. L. (1974), The Gospel According to Mark. The English Text with Introduction, Exposition and Notes, Grand Rapids, Eerdmans (New International Commentary on the New Testament).

Malbon, E. S. (1992), "Narrative Criticism. How does the Story Mean?» in J. C. Anderson and S. D. Moore, ed., Mark \& Method. New Approaches in Biblical Studies, Minneapolis, Fortress Press, p. 29-58.

Marguerat, D. and Y. Bourquin (19993) [French 2009, 1988]), How to Read Bible Stories / trans. by J. Bowden, London, SCM Press.

Merenlahti, P. (1999), "Characters in the Making. Individuality and Ideology in the Gospels ", in D. M. Rhoads and K. Syreeni, ed., Characterization in the Gospels. Reconceiving Narrative Criticism, Sheffield, Sheffield Academic Press (Journal for the Study of the New Testament Supplement Series 184), p. 49-72.

Miceli, C. A. (2011), "Undressing Jesus in the Gospel of Mark. A Narrative-Critical Analysis of the Clothing of the Character of Jesus ", M.A. Thesis, Concordia University, Montreal, Quebec.

Powell, M. A. (1990), What Is Narrative Criticism? A New Approach to the Bible, London, Society for Promoting Christian Knowledge.

Resseguie, J. L. (2005), Narrative Criticism of the New Testament. An Introduction, Grand Rapids, Baker Academic.

Uspensky, Boris $\left(1973^{2}\right)$, A Poetics of Composition, the Structure of the Artistic Text and Typology of a Compositional Form / trans. by V. Zavarin and S. Wittig, Berkeley, University of California Press.

YAMAsaki, G. (1998), John the Baptist in Life and Death. Audience-Oriented Criticism of Matthew's Narrative, Sheffield, Sheffield Academic Press (Journal for the Study of the New Testament, Supplement Series 167). 
(2006), "Point of View in a Gospel Story. What Difference Does

it Make? Luke 19,1-10 as a Test Case ", Journal of Biblical Literature, 125/1, p. 89-105.

(2007), Watching a Biblical Narrative. Point of View in Biblical Exegesis, London, T\&T Clark.

(2012), Perspective Criticism. Point of View and Evaluative Guidance in Biblical Narrative, Eugene, Cascade Books.

\section{Resumé}

Dans ses travaux récents, Watching a Biblical Narrative: Point of View in Biblical Exegesis (2007) et Perspective Criticism: Point of View and Evaluative Guidance in Biblical Narrative (2012), Gary Yamasaki présente une nouvelle méthodologie, intitulée Perspective Criticism, pour examiner les textes bibliques. Cet article démontre que la méthode proposée est un outil viable pour l'étude des textes bibliques. Il prend le récit de la Femme hémorragique (Marc 5,24-34) comme exemplaire. Dans ce texte, le lecteur implicite reçoit des informations sur l'histoire et la motivation de la femme hémorragique. Plutôt que de se concentrer uniquement sur le protagoniste Jésus, le narrateur déplace l'attention du lecteur sur la femme et explique ses échecs, au fil des ans, dans la recherche d'un remède à sa maladie. En employant la méthodologie perspective critique, l'étude soutient que l'auteur implicite a délibérément inséré cette information privilégiée, qui est anachronique au temps narratif de la péricope, afin de susciter l'empathie du lecteur avec la femme. Le récit offre la possibilité de voir les événements antérieurs du point de vue de la femme afin de comprendre son conflit tragique et de se rapprocher émotionnellement à ses pensées intérieures.

\section{Abstract}

In his recent works, Watching a Biblical Narrative: Point of View in Biblical Exegesis (2007) and Perspective Criticism: Point of View and Evaluative Guidance in Biblical Narrative (2012), Gary Yamasaki has introduced a new methodology, entitled Perspective Criticism, for analyzing biblical literature. The following paper seeks to evaluate whether or not this proposed method is a viable tool for use in the study of biblical texts. In order to do so, the account of the hemorrhaging woman (Mark 5: 24-34) is used as a test case. In the story, the implied reader is provided with background information about the history and motivation of the hemorrhaging woman. 
Rather than focusing solely on the protagonist Jesus, the narrator shifts the focus of the story onto the woman and explains her unsuccessful attempts, over the years, to find a cure for her ailment. In employing the Perspective Criticism methodology, the following paper argues that the implied author has purposefully inserted this privileged information, which is achronological to the narrative time of the pericope, in order to elicit empathy from the reader with the woman. The account offers the audience the ability to see previous events from the woman's point-of-view in order to understand her tragic struggle and emotionally connect with her inner thoughts. 